\title{
Correction to: A review of electrophysiological studies of lower motor neuron involvement in amyotrophic lateral sclerosis
}

\author{
Ali Amin Lari ${ }^{1}$ - Hamid Reza Bokaee ${ }^{1}$ Amer A. Ghavanini ${ }^{1,2}$
}

Published online: 3 April 2019

(C) Fondazione Società Italiana di Neurologia 2019

\section{Correction to: Neurological Sciences 2019 \\ https://doi.org/10.1007/s10072-019-03832-4}

The published version of this article unfortunately contained a mistake. The sequence of authorship and the corresponding author is incorrect. The correct sequence and corresponding author is presented here.

Publisher's note Springer Nature remains neutral with regard to jurisdictional claims in published maps and institutional affiliations.

The online version of the original article can be found at https://oi.org/ 10.1007/s10072-019-03832-4

\footnotetext{
Amer A. Ghavanini

ahmadamer.ghavanini@thp.ca

1 Canadian Neurological Center, Mississauga, ON, Canada

2 University of Toronto, Toronto, Canada
} 